\title{
Habitat use and space preferences of Eurasian Bullfinches (Pyrrhula pyrrhula) in northwestern Iberia throughout the year
}

Ángel Hernández ${ }^{1,2^{*}}$ (D)

\begin{abstract}
Background: For all vertebrates in general, a concerted effort to move beyond single season research is vital to improve our understanding of species ecology. Knowledge of habitat use and selection by Eurasian Bullfinches (Pyrrhula pyrrhula) is limited with regard to the non-breeding season. To date, research on the habitat of the Iberian subspecies iberiae consists of very general descriptions. In relation to space use, only broad features are available for the entire distribution range of Eurasian Bullfinches, including Iberia.
\end{abstract}

Methods: In this study, seasonal preferences regarding habitat and space in a population of Eurasian Bullfinches are examined for the first time in the Iberian Peninsula, through direct observation during a six-year period. The essential habitat components, substrate selection and perch height were assessed.

Results: Hedgerows were the key essential habitat component for bullfinches during all seasons. Nevertheless, small poplar plantations became increasingly important from winter to summer-autumn. Bullfinches perched mostly in shrubs/trees throughout the year, but there were significant seasonal changes in substrate use, ground and herbs being of considerable importance during spring-summer. Throughout the year, over half of the records corresponded to feeding, reaching almost $90 \%$ in winter. Generally, bullfinches perched noticeably lower while feeding. Male bullfinches perched markedly higher than females, notably singing males in spring-summer. Juveniles perched at a height not much lower than that of males. In all seasons, males tended to feed at greater heights than females. Bullfinches of different ages and sexes were seen bathing in all seasons except winter.

Conclusions: Hedgerow habitat in general appeared to be valuable for bullfinches throughout the year. In summer and autumn, they selected sites with an abundance of food and shade, as well as shelter, a much-needed requirement for fledglings and moulting individuals. There was usually a close link between the most used and most consumed plant species in each season. Males appeared to assume a more important role in vigilance, and often they accompanied dependent young in June and July. Bullfinch conservation strategies should consider seasonal demand for habitat and space.

Keywords: Habitat use, Perch height, Pyrrhula pyrrhula iberiae, Seasonal variation, Substrate selection, Water bathing

*Correspondence: ahernan@agro.uva.es

${ }^{1}$ Departamento de Ciencias Agroforestales, Área de Zoología, Universidad de Valladolid, Campus de Palencia, Palencia, España Full list of author information is available at the end of the article

\section{Background}

Habitat selection in birds, including passerines in temperate zones, is dynamic because the factors involved (e.g. food supply, vegetation physiognomy, predation risk) vary spatially and temporally, particularly throughout the year (Rice et al. 1980; Cody 1985; Wiens 1989; Hernández 1994; Marone et al. 1997; Dostine et al. 2001; Streby 
et al. 2014; Rechetelo et al. 2016). Different frameworks, ranging from macroscale (e.g. landscape level) to microscale descriptions (e.g. nest sites or foraging sites), should be taken into account when considering the spatial component of avian habitat selection (Jones 2001; Temple 2004; De Groot et al. 2010). Breeding productivity and survival, which mainly depend on accessibility to quality food and habitat, are fundamental factors in determining avian population size (Newton 1998; Gregory et al. 2004; Newton 2004). For all vertebrates in general, a concerted effort to move beyond single season research is vital to improve our understanding of species ecology and thus favour their conservation as there currently exists severe breeding season research bias (Marra et al. 2015).

Generally, small birds select habitats on the basis of conformational traits such as flora composition or vegetation height and density (Cody 1985; Wiens 1989; García-del-Rey and Cresswell 2005; Huang et al. 2014; Fourcade et al. 2018). For many typical passerine bird species in forested areas, hedgerows play an important role as foraging habitats or stepping stone for movement between woods, even providing the necessary resources both during and outside the breeding season (Gregory and Baillie 1998; Newton 1998; Robinson and Sutherland 1999; Hinsley and Bellamy 2000; Tellería et al. 2008; Wilson et al. 2009). Hedgerows have declined sharply in recent decades in Europe due to intensification of agricultural practices (see Cornulier et al. 2011).

In winter, European granivorous passerines linked to farmland prefer patches rich in seeds (e.g. hedgerow edges, stubbles) (Robinson and Sutherland 1999; Hancock and Wilson 2003; Stoate et al. 2003). On the other hand, at times of the year when they rely on fleshy fruit as their main source of food, partially frugivorous bird species select habitats not only for their vegetation structure (woody cover), but also for places where this resource is obtainable at any given moment as it is conspicuous and easily traceable and attainable even though its availability varies considerably in time and space (Herrera 1985; Tellería and Pérez-Tris 2007; Guitián and Munilla 2008; Martínez and García 2015).

Eurasian Bullfinches (Pyrrhula pyrrhula) (hereinafter referred to as bullfinches) are fringilids whose diet consists mostly of herb seeds and fleshy fruit, and are considered generalist forest birds that readily accept heterogeneous semi-open landscapes (Cramp and Perrins 1994; Glutz von Blotzheim and Bauer 1997; Wilson et al. 2009; Clement 2010). Knowledge of habitat use and selection by some bullfinch subspecies and populations during the breeding season, notably in central and western Europe, including the British Isles, is substantial, but limited with regard to the rest of the year (Newton 1985; Cramp and Perrins 1994; Farina 1997; Gregory and Baillie 1998; Siriwardena et al. 2000a, b; Marquiss 2007; Clement 2010). To date, knowledge of the habitat of the Iberian subspecies iberiae consists of very general descriptions, in particular concerning the breeding season and winter (Belamendia 2003, 2012; Díaz 2016). In relation to space use (e.g. perch height above ground), apart from the identity of plant species used for nest building or food plants, only broad features are available for the entire distribution range of bullfinches, including Iberia (Cramp and Perrins 1994; Díaz 2016).

In this study, habitat use and space preferences in a population of bullfinches in the Iberian Peninsula throughout the year are examined for the first time. According to preliminary surveys, they do not nest inside the relatively dry oak woods on the valley slopes surrounding the study area, nor are they seen there very often during the non-breeding season, presumably because of the lack of moisture and undergrowth cover, preferring the valley bottom. Thus, the target population occupies a hedgerow-dominated landscape in northwestern Spain, in an area close to the southwestern limit of distribution of the species. The main parameters analysed are: (1) essential habitat components, that is, clearly distinguishable structural elements of vegetation, (2) substrate use and selection (use of shrubs/trees versus ground/herbs, plant species use, and shrub/tree species preferences) not necessarily in relation to feeding habits, and (3) perch height. Water bathing, included as ground substrate use, is described in some detail (seasonal frequency of occurrence, sex and age of the individuals involved, way of bathing) as this behaviour is not documented for the bullfinch and is hardly dealt with in the bird literature (Verbeek 1991; Brilot et al. 2009).

This study is in line with the need to compensate for the noticeable increment in modeling and existing data analyses in biological sciences, so that ornithologists have been urged to determine the ecology of poorly investigated avian taxa by means of field investigation, and in this respect bird subspecies may be of great relevance (Phillimore and Owens 2006; Ríos-Saldaña et al. 2018).

\section{Methods}

\section{Study area}

The study area covers 78 ha and is located in the middle-lower Torío river valley, between Palacio and Manzaneda $\left(42^{\circ} 43^{\prime}-42^{\circ} 44^{\prime} \mathrm{N}, 5^{\circ} 30^{\prime}-5^{\circ} 31^{\prime} \mathrm{W}\right.$; $900 \mathrm{~m}$ a.s.l.; León province, Castile and Leon autonomous community), in northwest Spain. Biogeographically, it forms part of the Carpetano-Leonese sector in the Mediterranean West Iberian province (Rivas-Martínez 2007). Hot summers (average temperature of $\approx 20{ }^{\circ} \mathrm{C}$ ), cold winters $\left(\approx 4{ }^{\circ} \mathrm{C}\right)$ with some snowfall, and moderate rainfall (average annual precipitation of $\approx 500 \mathrm{~mm}$ ) 
with a relatively short dry summer season characterize the area. The landscape is mainly composed of hedgerows that separate irrigated meadows grazed by livestock and cut for hay, bordered by riparian woodland on the west side and slopes covered in Pyrenean Oak (Quercus pyrenaica) woods interspersed with very small Scots Pine (Pinus sylvestris) plantations on the east side (Fig. 1). Some hedgerows border Canadian Poplar (Populus $\times$ canadensis) plantations. Estimated hedgerow density is $3.3 \mathrm{~km} / 10$ ha. This area is located in a transition zone to the Eurosiberian region, south of the Cantabrian mountain range, in an extensive hedgerow network of great conservation value for flora and fauna (Hernández 2009, 2014, 2018; Hernández and Zaldívar 2013, 2016). About thirty species of broadleaved, chiefly deciduous shrubs, trees and climbers are found in the hedgerows. The landscape and hedgerow density and structure are very similar throughout the study area and have hardly changed in recent years and decades, except for a moderate increase in the number of poplar plantations and an incipient abandonment of meadows and hedges.

\section{Data collection}

General procedures

Throughout 2001-2006, the bullfinches directly observed in the study area and maximum details of sightings were recorded during field trips conducted to investigate their general ecology. In a systematic way, 41 trips were conducted in winter (December to February), 113 in spring (March to May), 155 in summer (June to August) and 84 in autumn (September to November). The total number of trips in each season was equally distributed among the years of study as far as possible, except for 2006 when the sampling effort was considerably lower. Two trips were usually needed to cover the entire area: approximately half of the area (36 ha) on one trip, and the rest (42 ha) the following day. On each trip, the corresponding zone was explored by slowly walking around it, stopping frequently, following the hedgerows edges and marginally $(\approx 10 \%$ sampling effort) oak wood edges. Small European birds generally show a bimodal pattern of daily locomotor activity, but mobility tends to decrease throughout the day (Bas et al. 2007 and references therein). On this basis, more than $85 \%$ of field trips were conducted in the morning in all seasons, and the remainder in the afternoon. The morning trips lasted from one hour

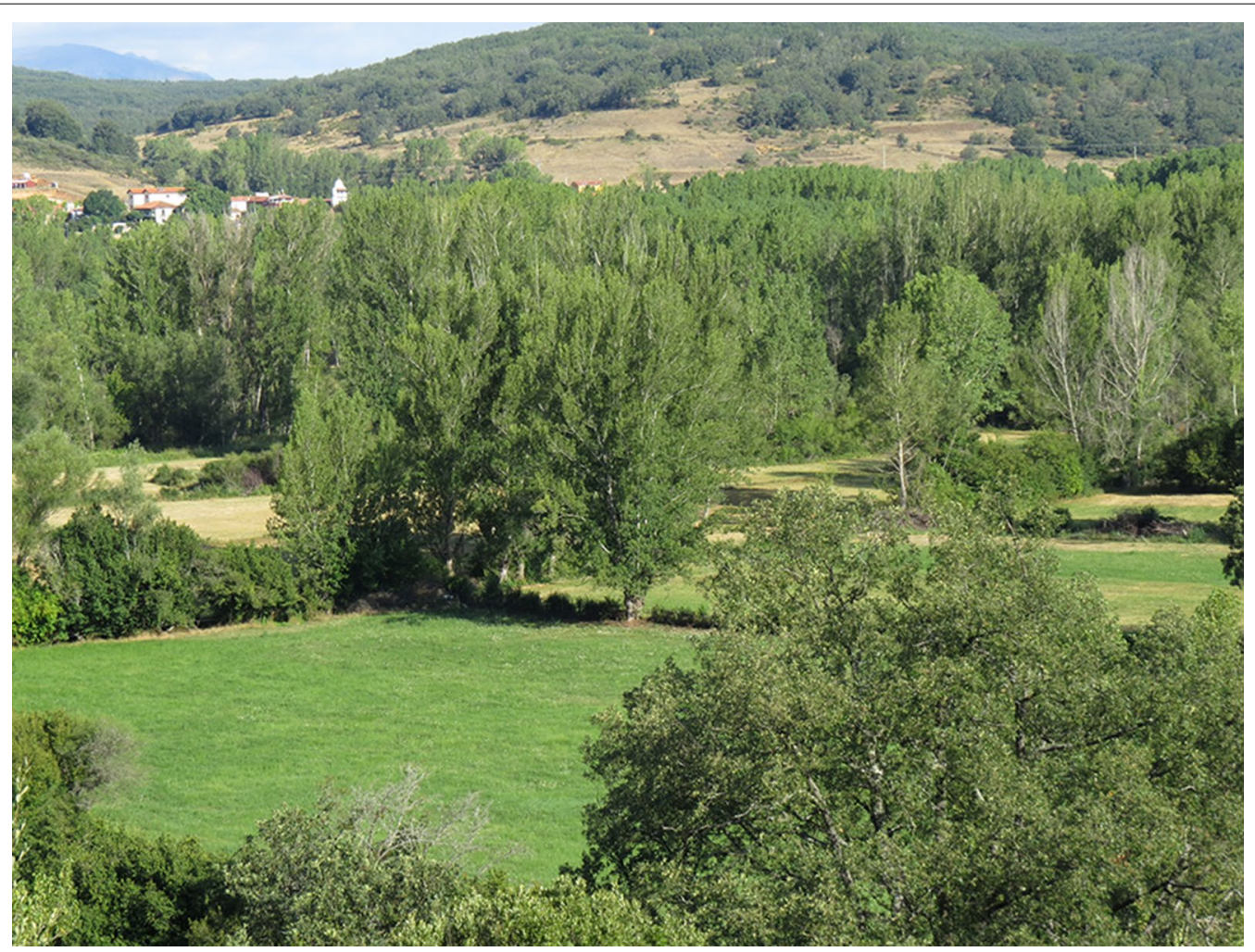

Fig. 1 Partial view of the study area, located in NW Spain, showing the hedgerow network landscape in the foreground 
after sunrise to $12: 00 \mathrm{~h}$ (solar time) and the afternoon trips from 12:00 $\mathrm{h}$ (solar time) to one hour before sunset, as there was insufficient light at dawn or dusk for sampling to be carried out. As far as possible, the records were independent of one another, that is, they corresponded to different individuals, pairs or family groups, at least those for each systematic sampling day. Males and females include individuals in apparently full adult plumage, and juvenile individuals in juvenile plumage (apparently complete or already moulting) either still dependent on their parents or independent.

Bullfinches are particularly inconspicuous when breeding (Newton 1985; Á. Hernández pers. obs.), but their contact calls and songs, composed mainly of piping notes emitted at fairly low volume, enabled them to be located. Also, the observer mimicking their voices to get the birds to answer was quite a successful technique, as verified by Newton (1985). Bullfinch density in the area and study period was approximately 2.5-3.5 pairs/10 ha during April-May, according to complete counts covering the entire study area.

\section{Main habitat components}

To establish habitat use, each record refers to an encounter with the species regardless of the number, sex and age of the detected individuals. Bullfinches are gregarious birds, even more so during the non-breeding season, often forming mixed groups of males and females, parties not usually exceeding 10 individuals (Cramp and Perrins 1994; Á. Hernández unpubl. data). Both individuals observed directly and those heard but not seen were considered, but adult and young birds in the nest were not. Occurrence (presence) of habitat components in a $25 \mathrm{~m}$ radius was estimated for each record. Habitat components considered were hedgerow, oak woodland edge, riverside woodland, irrigation ditch, dirt track, poplar plantation, fruit orchard and brushwood. Since habitat components are linear or cover, individually, a small area, a $25 \mathrm{~m}$ radius is sufficient to detect the presence of various different components in the immediate vicinity of the bullfinches but without repetition. Diversity of bullfinch habitat in each season was estimated as the sum of habitat component occurrences divided by the number of bullfinch records. The following types of hedgerows were considered: open (delimiting large plots), closed (delimiting small plots) and semi-open (intermediate situation). Most hedgerows were assumed to be associated to meadows. Other habitat components, such as alfalfa and corn fields, occasionally appeared instead of meadows. Irrigation ditches and dirt tracks were usually bordered by woody vegetation.

\section{Substrate selection and perch height}

To establish space use, focal sampling (as explained by Sutherland 2004) for a short time was conducted, so each individual identified by sex and age, and perched on a specific substrate (excluding nest), whether feeding or not, was observed for a maximum period of $10 \mathrm{~min}$ and produced at least one substrate record. An individual produced more than one record if it moved to eat on different substrates, without considering more than one record per substrate or the units (quantity) ingested. However, the aim of this study is not to determine bullfinch foraging tactics and diet, which are dealt with in other research (Á. Hernández unpubl. data). Overall records, if not otherwise specified, are feeding plus non-feeding records. Bullfinches normally ingest food in the place where they find it. An individual could be perched on a plant, i.e. the substrate concerned, whilst feeding from another of a different species. If consuming plant food while flying, the consumed plant species was considered a substrate. If the individual was eating an arthropod, the plant species on which it was perched was considered, even though the prey was caught in flight. If the individual was not feeding, a record was made of whether it was singing or not, considering only males singing in spring and summer, as the most elaborate song, which is different to contact calls, was scarcely heard during the rest of the year and, although both sexes can sing (Wilkinson 1990; Cramp and Perrins 1994; Á. Hernández pers. obs.), females apparently only did so occasionally. Sightings of birds flying were not taken into consideration. Perch height was visually estimated for each record, 0 being on the ground. The lowest heights $(<3 \mathrm{~m})$ were usually estimated with an accuracy of $0.1 \mathrm{~m}$, those relatively low $(3-5 \mathrm{~m})$ with $0.5 \mathrm{~m}$, and those highest $(>5 \mathrm{~m}$ ) with $1 \mathrm{~m}$. The height recorded corresponds to that occupied by the individual on each substrate when first observed. The substrates considered were the different plant types (different identified taxa, unidentified shrub/tree, unidentified herb), ground, and "others" (low stake, low wire fence, pile of branches on the ground, fallen tree, power line). A record was also made when an individual bathed during the 10-minute observation period. The bathing place, usually irrigation ditches in hedgerow borders, was considered a ground substrate.

Plant species availability as perch substrate was estimated by conducting eight sampling days within the period 28 September-15 October 2005, when approximately $9 \mathrm{~km}$ of hedgerows were covered $(\approx 35 \%$ of all the hedgerows, evenly distributed in the study area), recording the presence-absence, but not the number of individuals of each species (shrubs, trees, climbers) in $2 \mathrm{~m}$ long fragments ( $n=330$ fragments) situated every 25 m (modified from Hernández and Alegre 1991). 
Multispecific complexes of Populus poplars (P. nigra, $P$. $\times$ canadensis, $P$. tremula), Salix willows (mainly $S$. fragilis, also $S$. atrocinerea, $S . \times$ secalliana), Rubus brambles (mainly $R$. ulmifolius, also $R$. caesius), Rosa roses (mainly $R$. canina) and Malus apples (M. domestica, some $M$. sylvestris) were classified as single species. Pyrus communis included $P$. communis var. pyraster; and Prunus spinosa included $P$. insititia and $P$. domestica. Selection of each plant species was estimated by the Jacobs' index (Jacobs 1974): $S=(u-a) /(u+a-$ $2 u a$ ), where $u$ (use) is the proportion of occurrences as perch substrate of a given plant species in relation to total plant use occurrences, and $a$ (availability) is the proportion of occurrences of that plant species in the hedgerows in relation to the total occurrences of all plant species. Correction of $u$ and $a$ values for a total of 1 is required for calculations. This index varies between -1 (maximum negative selection) and 1 (maximum positive selection), with a value 0 if selection does not occur (i.e. bullfinches used the plant species according to its availability). However, a conservative approach was taken, considering non-selection the interval from -0.2 to 0.2 , moderate selection $0.21-0.5$ (negative or positive) and strong selection 0.51-1 (negative or positive). The maximum height of each hedge fragment was visually estimated, in the same way as perch height, in order to compare both heights.

\section{Statistical analysis}

The Chi-square test $\left(\chi^{2}\right)$ was used to compare absolute frequencies for two variables; log-linear analysis $\left(G^{2}\right)$ to compare absolute frequencies for three variables $(2 \times 2 \times 2$ tables); unpaired $t$-test to compare two means; and two-way ANOVA $(F)$ to estimate how two independent variables, in combination, affect the mean of a dependent variable; considering the twotailed way wherever possible (Fowler et al. 1998; Lowry 1998-2020). For large sample sizes, such as those in this study, the normality assumption required for parametric tests is of minor importance (see Ghasemi and Zahediasl 2012). $P<0.05$ was considered statistically significant. All years were pooled together to avoid analysing small sample sizes. As stated above, the sampling effort in each season was equally distributed among the years of study. Also, little changing environmental conditions from year to year seemed to promote steady breeding population densities during the study period. Interannual variation in diet was not remarkable, and nest success and breeding productivity rates were fairly constant from one year to the next (Hernández 2021; Á. Hernández unpubl. data).

\section{Results}

\section{Main habitat components}

The frequency of occurrence of hedgerows in the immediate habitat of the bullfinch (a $25 \mathrm{~m}$ radius) was very high throughout the year, and was always within 94-96\% of the records ( $n=144$ bullfinch records in winter, 444 in spring, 805 in summer, 428 in autumn). The second most important habitat component was poplar plantation, although with notable seasonal differences in frequency of occurrence, increasing from a minimum of $15 \%$ in winter to $24 \%$ in spring and a maximum of $49 \%$ in summer, and decreasing to $40 \%$ in autumn. Oak woodland edges appeared all year in 11-15\% of records, the highest values in this interval occurring in winter-spring. Other habitat components had generally lower values for frequency of occurrence, usually $1-10 \%$, with an increase within this range in summer-autumn for riverside woodland, irrigation ditch and dirt track, the latter even exceeding the interval in autumn (15\%). Brushwood appeared most in winter $(\approx 10.5 \%)$ and least in summer $(\approx 6 \%)$. Diversity of bullfinch habitat increased from winter (212 habitat component occurrences in 144 bullfinch records: ratio of 1.47) to spring (707/444, 1.59 occurrences/record) and summer-autumn (1505/805 and 797/428, 1.87 and 1.86, respectively) (Fig. 2). There was a significant association between occurrences of each habitat component and season $\left(\chi_{21}^{2}=122.00, P<0.001\right)$, that is, a significant variation in habitat composition throughout the year.

Considering only occurrence of hedgerows, the open type was the most important one in winter ( $40 \%$ of 138 winter occurrences; $25-35 \%$ for the other types), the

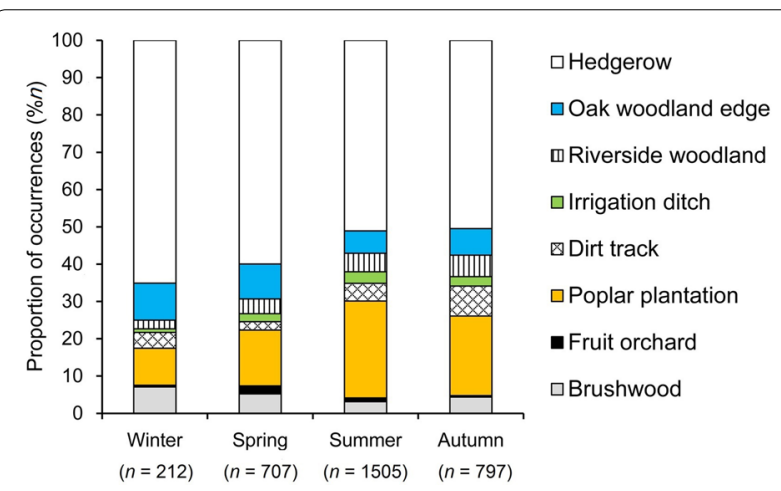

Fig. 2 Seasonal habitat use by Iberian bullfinches in NW Spain considering proportion of occurrences for habitat components in a $25 \mathrm{~m}$ radius around bullfinch records (encounters with the species regardless of the number of individuals detected in each encounter). Data correspond to 2001-2006. Winter: December to February. Spring: March to May. Summer: June to August. Autumn: September to November. $n$ : total number of occurrences of habitat components per season for 144 winter, 444 spring, 805 summer and 428 autumn bullfinch records 
semi-open type in spring (55\% of $424 ; 15-30 \%$ for the other types), the closed and semi-open types in summer ( $50 \%$ and $45 \%$, respectively, of $769 ; 5 \%$ for the open type), and the closed type in autumn (55\% of 402; $35 \%$ and $10 \%$ for semi-open and open types, respectively), resulting in significant seasonal differences $\left(\chi_{6}^{2}=178.88, P<0.001\right)$.

\section{Substrate selection}

Grouping related substrates together, that is, only differentiating between shrubs/trees and ground/herbs/others, the proportion of bullfinch records in shrubs/trees, considering sex and age separately, was highest in winter (> $97 \%$ in all cases), slightly lower in autumn (>91\%), and decreased noticeably in spring $(<85 \%)$ and, more sharply, in summer $(<66 \%)$ (Fig. 3). Considering substrate (these groupings), sex of adult individuals (male and female) and time of year (breeding and non-breeding seasons, i.e. spring-summer and autumn-winter respectively), there were significant general differences in the frequencies of bullfinch records $\left(G_{4}^{2}=201.93, P<0.001\right)$. More specifically, in each sex there were significant differences between breeding and non-breeding season (males: $G_{1}^{2}$ $=129.47, P<0.001,74.3 \%$ and $96.9 \%$ of the records corresponding to shrub/tree substrate in the respective seasons; females: $G_{1}^{2}=71.23, P<0.001,73.5 \%$ and $95.1 \%$ ), but not in each time period between males and females (breeding: $G_{1}^{2}=0.10, P>0.05,74.3 \%$ and $73.5 \%$ of the records corresponding to shrub/tree substrate in the respective sexes; non-breeding: $G_{1}^{2}=1.63, P>0.05,96.9 \%$ and $95.1 \%)$. Taking into account age (adults, considering both sexes together, and juveniles), substrate (the same groupings) and season (summer and autumn), there were significant general differences in the frequency of bullfinch records $\left(G_{4}^{2}=264.60, P<0.001\right)$. More specifically, in each age there were significant differences between summer and autumn (adults: $G_{1}^{2}=137.28, P<0.001$, $62.0 \%$ and $94.0 \%$ of the records corresponding to shrub/ tree substrate in the respective seasons; juveniles: $G_{1}^{2}=$ 63.66, $P<0.001,65.8 \%$ and $91.5 \%$ ), but not in each season between adults and juveniles (summer: $G_{1}^{2}=1.92, P$ $>0.05,62.0 \%$ and $65.8 \%$ of the records corresponding to shrub/tree substrate in the respective ages; autumn: $G_{1}^{2}=$ $1.20, P>0.05,94.0 \%$ and $91.5 \%)$. Overall, the importance of ground was moderately high in spring and summer $(8-13 \%)$ and that of herbs in summer $(25-30 \%)$, while "others" was irrelevant throughout the year (Table 1).

Irrespective of the sex or age, over half of the bullfinch records corresponded to feeding throughout the year, increasing from breeding to non-breeding season (Table 1). Grouping all substrates and individuals together, the percentage of feeding records, as compared with non-feeding records, decreased in the order winter (88\%), autumn (64\%), spring (62\%), summer $(58 \%)\left(\chi_{3}^{2}=\right.$ 134.04, $P<0.001)$.

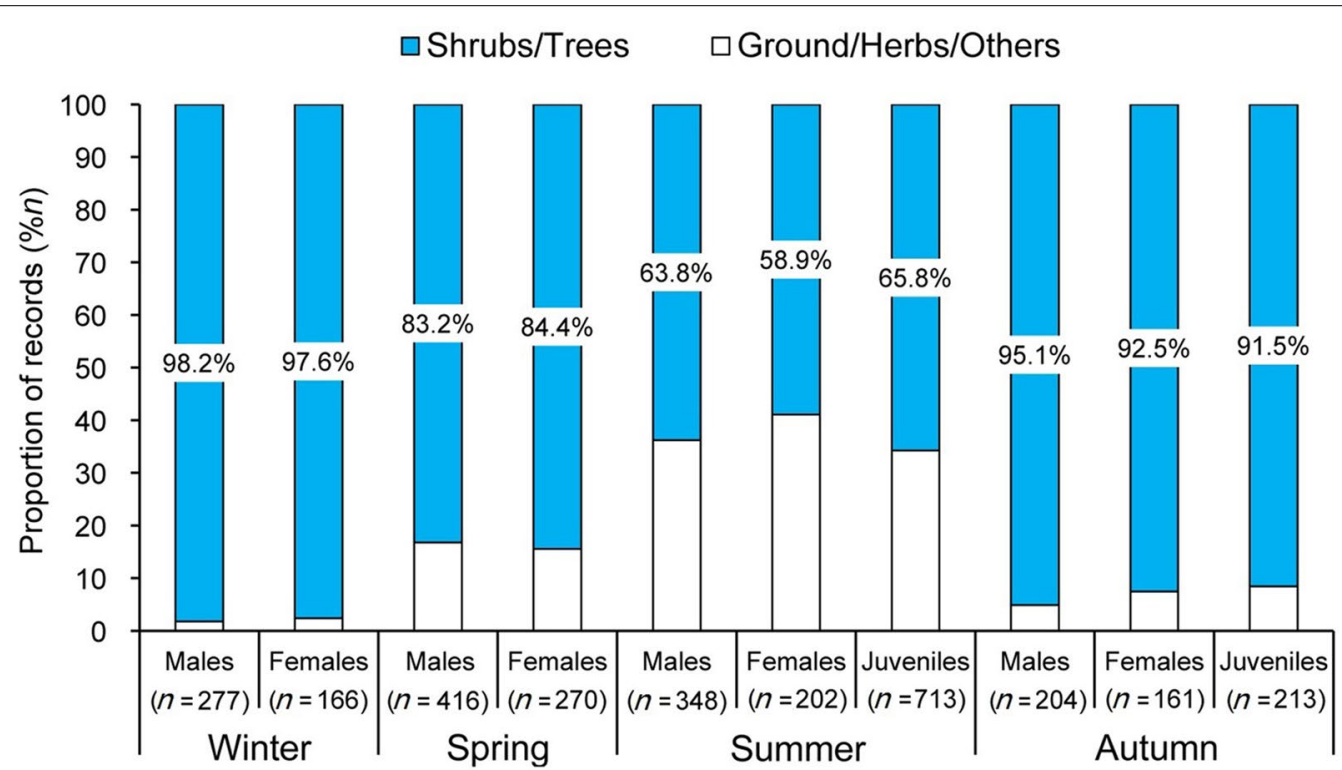

Fig. 3 Seasonal use of general substrates by Iberian bullfinches in NW Spain, differentiating sex and age. Data correspond to 2001-2006. Winter: December to February. Spring: March to May. Summer: June to August. Autumn: September to November. $n$ : number of records. Each record refers to an individual perched on a specific substrate, sighted and identified by sex and age, whether eating or not. See "Methods" for further clarification of record definition regarding substrate use. Number of individuals observed: winter-166 males, 117 females; spring —368 m, 235 f; summer-265 m, 185 f, 696 juveniles; autumn—179 m, 132 f, 164 j. Other substrates ("Others"): low stake, pile of branches and fallen tree in spring; low wire fence, pile of branches and fallen tree in summer; power line in autumn 


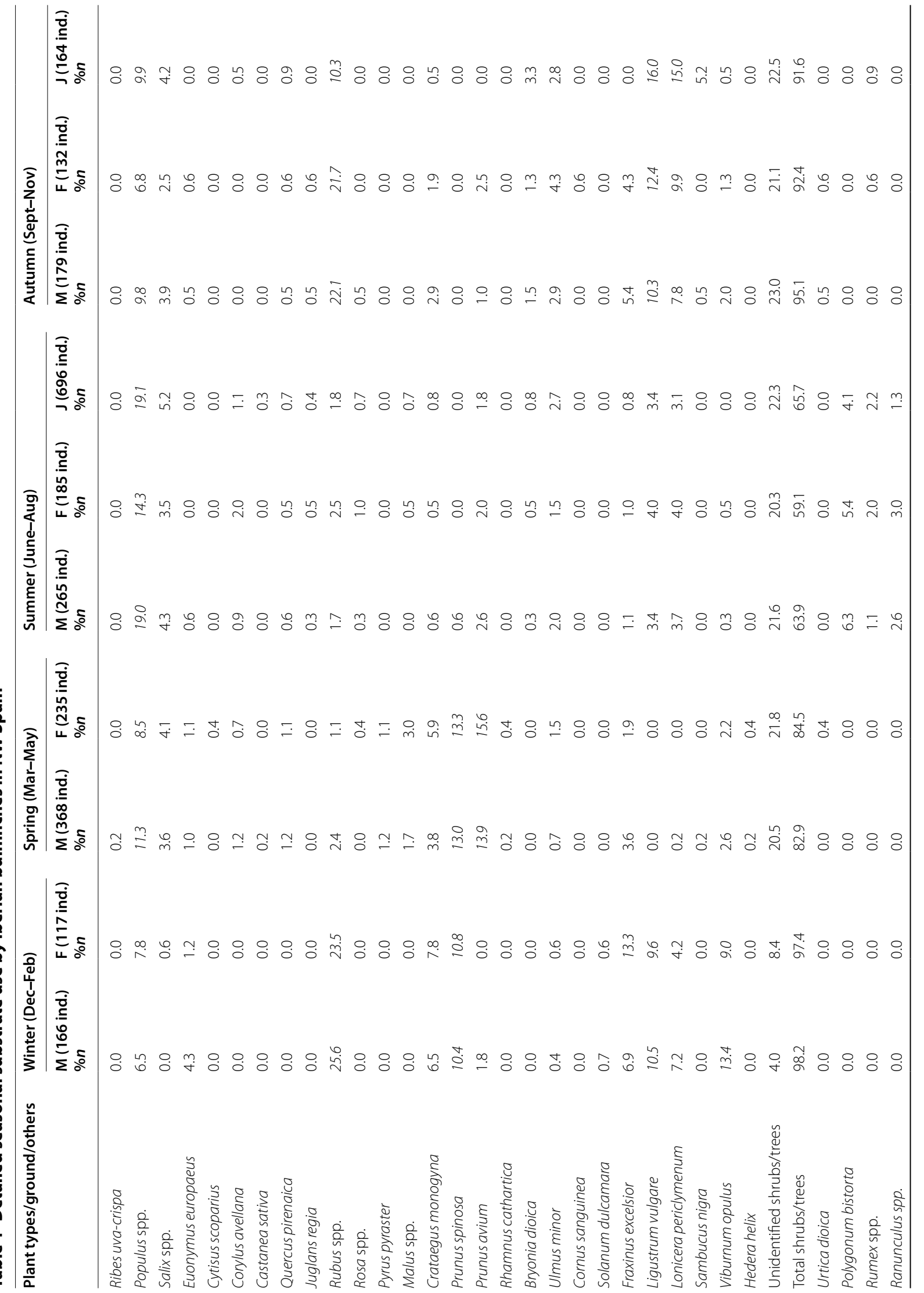




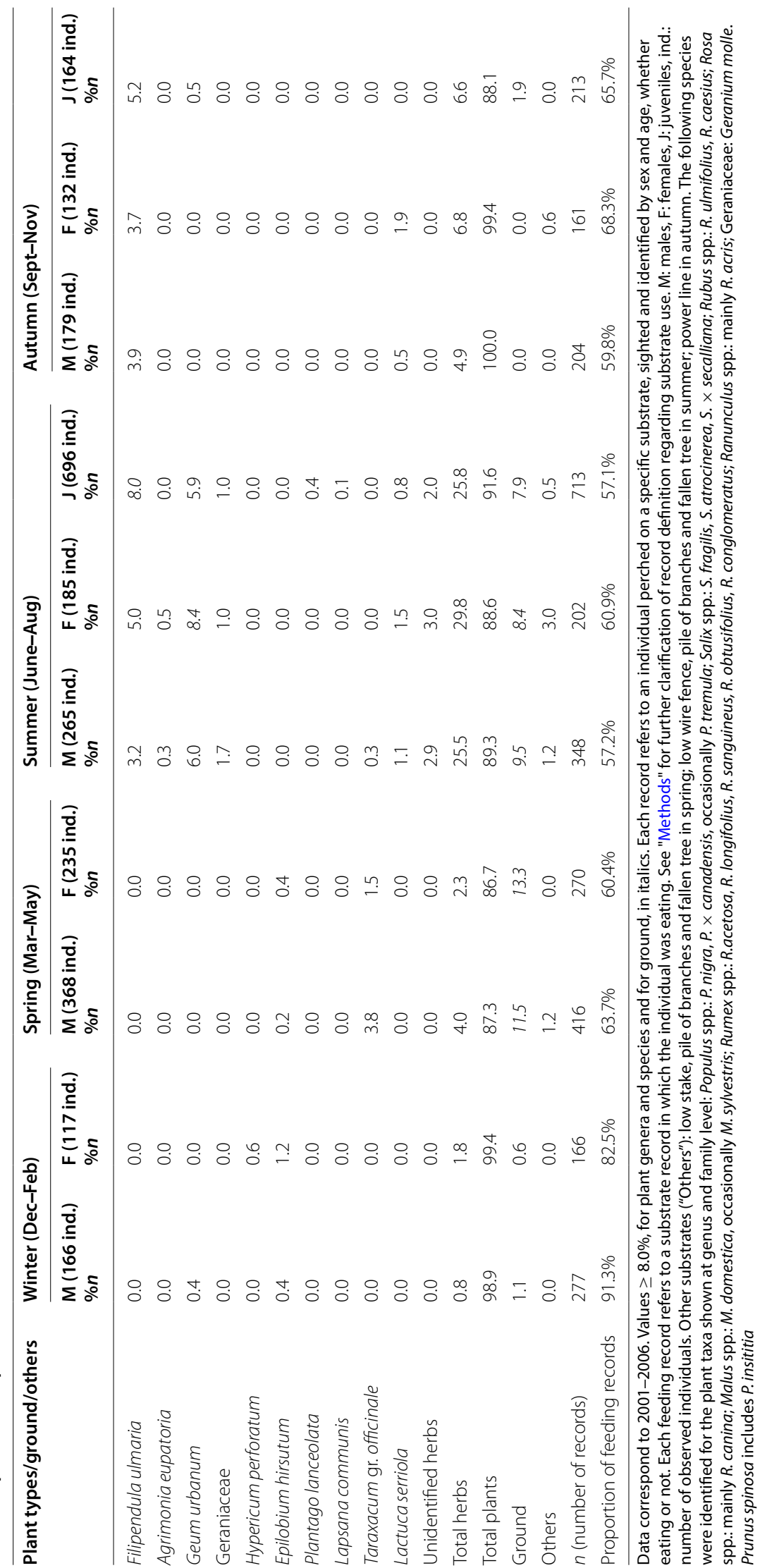


Taking into account identified plants, Rubus brambles ( $25 \%$ of records) were the most frequently used in winter, followed by other shrubs/trees, namely, Prunus spinosa, Fraxinus excelsior, Ligustrum vulgare and Viburnum opulus (7-14\%); in spring, P. avium, P. spinosa and Populus poplars (9-16\%) were important, and among herbs only Taraxacum officinale was used with certain frequency (just under 4\%); poplars (14-19\%) and some herbs, mostly Polygonum bistorta, Geum urbanum and Filipendula ulmaria (4-9\%), were the most frequently used in summer; and brambles (up to 22\%) in autumn, followed by other shrubs/trees and climbers, in particular poplars, L. vulgare and Lonicera periclymenum (7-16\%), and F. ulmaria herbs (4-5\%) (Table 1).

Considering only the most commonly used and/or available identified shrubs/trees and climbers, bullfinches selected $F$. excelsior and $L$. periclymenum very positively, and $V$. opulus, brambles and poplars moderately, in winter; they selected P. avium and poplars very positively, and P. spinosa and Salix willows moderately, in spring; in summer, they selected poplars, L. periclymenum and willows very positively; and in autumn, $L$. periclymenum very positively and poplars, $L$. vulgare, brambles and willows moderately (Table 2). Nine of these 17 cases of positive selection were linked to plants included in the five shrubs/trees/climbers most consumed in the corresponding season (Table 2). Considerable percentages (46-93\%) of the substrate use records referring to shrubs/ trees/climbers were feeding records (Table 2). Some shrubs/trees with notable availability, such as Euonymus europaeus, Corylus avellana, Rosa roses, Crataegus monogyna, Ulmus minor and Cornus sanguinea, were negatively selected as perches to a moderate/large extent, or were used according to their availability, throughout the year (Table 2).

\section{Water bathing}

Bullfinches only bathed in April-September, according to a total of 25 sightings involving 36 individuals. The proportion of individuals bathing in comparison with the total number of individuals recorded for the space use analysis was $1.2 \%$ in spring (7 of 603), $2.0 \%$ in summer (23 of 1146) and 1.3\% in autumn (6 of 475). All sightings of bathing were recorded in the morning, except for one in the afternoon, and corresponded to males $(n=9)$, females $(n=5)$ and apparently independent juveniles $(n$ $=22$ ). The number of individuals per sighting was $1-3$. In 22 sightings all of the bullfinches bathed, and in three not all of them did. However, they could have bathed before or after the sighting. The three sightings were of two pairs (in one case only the male bathed, and in the other only the female) and a family group consisting of a pair and four dependent young individuals in which only the male bathed. If more than one individual bathed, it was usually one by one. On three occasions, they bathed with another bird species, namely European Serin (Serinus serinus), Eurasian Blackcap (Sylvia atricapilla) and Eurasian Blue Tit (Cyanistes caeruleus), respectively. They bathed in a thin layer of water for up to 2-3 min. The main movements, repeated several times, were: spongeing and separating feathers all over the body, fluttering wings in the water, and dipping the head and front part of the body in the water whilst turning sideways in both directions. After bathing, they flew up to the branches of shrubs/ trees at different heights $(1.5-12 \mathrm{~m})$ to shake and preen until they had dried off.

\section{Perch height}

Considering overall records, that is, grouping feeding and non-feeding records together, the range of mean perch heights occupied by bullfinches, differentiating between males, females and juveniles, and between seasons, was 2.51-4.49 m (females in summer-males in spring) (Fig. 4). Considering overall records for males and females, there was no significant combined effect of season and sex on mean perch height $\left(F_{3,2036}=1.99, P=\right.$ 0.11 ), but there were seasonal differences when grouping sexes together $\left(F_{3,2036}=14.86, P<0.001 ; 3.69 \mathrm{~m}\right.$ in winter, 4.21 in spring, 2.94 in summer, 4.16 in autumn) and differences between males and females when grouping seasons together $\left(F_{1,2036}=6.04, P=0.01 ; 3.90\right.$ and 3.50 $\mathrm{m}$, respectively). Taking into account overall records for males, females and juveniles during summer and autumn, there was a significant combined effect of season and bird category on mean perch height $\left(F_{2,1835}=3.44, P=\right.$ $0.03)$ and there were seasonal differences when grouping bird categories together $\left(F_{1,1835}=23.84, P<0.001 ; 3.17\right.$ $\mathrm{m}$ in summer versus $4.04 \mathrm{~m}$ in autumn), but there were no differences between bird categories when grouping both seasons together $\left(F_{2,1835}=1.49, P=0.23 ; 3.59 \mathrm{~m}\right.$ for males, 3.18 for females, 3.46 for juveniles).

Distinguishing between feeding and non-feeding records (activity categories), there was a significant combined effect of season and activity category on mean perch height, and there were differences between seasons when grouping activity categories together, and also between activity categories when grouping seasons together, for both males (two-way ANOVA, $P<0.001$ in each of these cases; $n=1245$ total records) and females (two-way ANOVA, $P<0.001$ in each of these cases; $n=779$ total records). Grouping activity categories together, mean perch height ranged from $3.19 \mathrm{~m}$ in summer to $4.49 \mathrm{~m}$ in spring for males, and from 2.51 $\mathrm{m}$ in summer to $4.01 \mathrm{~m}$ in autumn for females (Fig. 4). Grouping seasons together, mean perch height ranged from $3.28 \mathrm{~m}$ when feeding to $5.19 \mathrm{~m}$ when non-feeding 
Table 2 Seasonal substrate selection by Iberian bullfinches in NW Spain referring to shrubs and trees, including climbing plants

\begin{tabular}{|c|c|c|c|c|c|c|c|c|c|}
\hline \multirow[t]{2}{*}{ Plant types } & \multirow[t]{2}{*}{ Avail. $(\% n)$} & \multicolumn{2}{|c|}{ Winter (Dec-Feb) } & \multicolumn{2}{|c|}{ Spring (Mar-May) } & \multicolumn{2}{|c|}{ Summer (June-Aug) } & \multicolumn{2}{|c|}{$\begin{array}{l}\text { Autumn (Sept- } \\
\text { Nov) }\end{array}$} \\
\hline & & $U(\% n)$ & $s$ & $U(\% n)$ & $S$ & $U(\% n)$ & $S$ & $U(\% n)$ & $S$ \\
\hline Ribes uva-crispa & 0.2 & 0.0 & -1 & 0.2 & 0.0 & 0.0 & -1 & 0.0 & -1 \\
\hline Populus spp. & 5.0 & 7.6 & 0.22 & 16.3 & $\underline{0.57}$ & 43.2 & $\underline{0.87}$ & 12.7 & 0.47 \\
\hline Salix spp. & 3.2 & 0.2 & -0.89 & 6.0 & 0.32 & 11.0 & $\underline{0.58}$ & 5.1 & 0.24 \\
\hline Euonymus europaeus & 5.1 & 3.4 & -0.21 & 1.6 & $=\underline{0.54}$ & 0.4 & $=0.86$ & 0.5 & $=\underline{0.83}$ \\
\hline Cytisus scoparius & 0.0 & 0.0 & - & 0.2 & 1.0 & 0.0 & - & 0.0 & - \\
\hline Corylus avellana & 5.9 & 0.0 & $=1$ & 1.6 & $=\underline{0.59}$ & 2.8 & -0.37 & 0.2 & $=\underline{0.94}$ \\
\hline Castanea sativa & 0.0 & 0.0 & - & 0.2 & 1.0 & 0.4 & 1.0 & 0.0 & - \\
\hline Quercus pyrenaica & 0.8 & 0.0 & -1 & 1.9 & 0.41 & 1.5 & 0.31 & 1.0 & 0.11 \\
\hline Juglans regia & 0.2 & 0.0 & -1 & 0.0 & -1 & 0.9 & 0.64 & 0.5 & 0.43 \\
\hline Rubus spp. & 16.2 & 26.9 & $0.31 *$ & 3.0 & $=\underline{0.72}$ & 4.5 & $=\underline{0.61}$ & 24.9 & $0.26^{*}$ \\
\hline Rosa spp. & 10.1 & 0.0 & $=1$ & 0.2 & $=\underline{0.96}$ & 1.5 & $=0.76$ & 0.2 & $=\underline{0.96}$ \\
\hline Pyrus communis & 0.05 & 0.0 & -1 & 1.9 & 0.95 & 0.0 & -1 & 0.0 & -1 \\
\hline Malus spp. & 0.3 & 0.0 & -1 & 3.5 & 0.85 & 1.1 & 0.57 & 0.0 & -1 \\
\hline Crataegus monogyna & 6.9 & 7.6 & 0.05 & 7.4 & 0.04 & 1.7 & $=0.62$ & 2.4 & -0.50 \\
\hline Prunus spinosa & 8.0 & 11.5 & 0.20 & 20.9 & $0.50 *$ & 0.4 & $=0.91$ & 0.0 & $=1$ \\
\hline Prunus avium & 0.8 & 1.2 & 0.20 & 23.3 & $\underline{0.95^{*}}$ & 4.9 & 0.73 & 1.5 & 0.31 \\
\hline Rhamnus cathartica & 0.2 & 0.0 & -1 & 0.5 & 0.43 & 0.0 & -1 & 0.0 & -1 \\
\hline Bryonia dioica & 0.9 & 0.0 & -1 & 0.0 & -1 & 1.5 & 0.25 & 2.9 & 0.53 \\
\hline Ulmus minor & 5.3 & 0.5 & $=0.84$ & 1.6 & $=0.55$ & 5.4 & 0.0099 & 4.6 & -0.07 \\
\hline Humulus lupulus & 0.2 & 0.0 & -1 & 0.0 & -1 & 0.0 & -1 & 0.0 & -1 \\
\hline Cornus sanguinea & 6.9 & 0.0 & $=1$ & 0.0 & $=1$ & 0.0 & $=1$ & 0.2 & $=0.95$ \\
\hline Solanum dulcamara & 0.2 & 0.7 & 0.56 & 0.0 & -1 & 0.0 & -1 & 0.0 & -1 \\
\hline Fraxinus excelsior & 1.05 & 10.0 & $\underline{0.83^{*}}$ & 4.7 & 0.65 & 2.2 & 0.36 & 4.4 & 0.63 \\
\hline Ligustrum vulgare & 9.7 & 11.0 & 0.07 & 0.0 & $=1$ & 8.2 & -0.09 & 18.3 & $0.35^{*}$ \\
\hline Lonicera periclymenum & 1.5 & 6.6 & $\underline{0.65}$ & 0.2 & -0.77 & 8.0 & $\underline{0.70^{*}}$ & 15.6 & $\underline{0.85^{*}}$ \\
\hline Sambucus nigra & 0.7 & 0.0 & -1 & 0.2 & -0.56 & 0.0 & -1 & 2.9 & 0.62 \\
\hline Viburnum opulus & 6.0 & 12.7 & $0.39 *$ & 4.0 & -0.21 & 0.4 & $=0.88$ & 1.7 & $=0.56$ \\
\hline Hedera helix & 4.6 & 0.0 & -1 & 0.5 & -0.81 & 0.0 & -1 & 0.0 & -1 \\
\hline$n$ (number of records) & 1817 & 409 & & 430 & & 535 & & 409 & \\
\hline Feeding records (\%n) & & 92.7 & & 67.9 & & 46.2 & & 81.2 & \\
\hline
\end{tabular}

Substrate records (U: use) correspond to data on 2001-2006. Each substrate record refers to an individual, sighted and identified by sex and age, perched on a plant type identified at genus or species level, whether eating or not. Each feeding record refers to a substrate record in which the individual was eating. See "Methods" for further clarification of record definition regarding substrate use. In winter and spring, males and females are considered together; in summer and autumn, males, females and juveniles together. See "Methods" for detailed information on assessment of plant species availability as perch substrate (Avail.). Selection index (S) (Jacobs 1974) varies between - 1 (maximum negative selection) and 1 (maximum positive selection), with a value of 0 if selection does not occur (i.e. bullfinches used the plant species according to its availability). In bold: positive moderate selection ( 0.21 to 0.50$)$. In bold and underlined: strong positive selection (0.51 to 1$)$. In italics: moderate negative selection $(-0.21$ to -0.50$)$. In italics and underlined: strong negative selection $(-0.51$ to -1$)$. Only values for plants with certain relevance are highlighted, that is, \%n>5 regarding availability, use, or both. *: plant types, with moderate or strong positive selection, amongst the 5 most consumed foods in each season, considering shrubs and trees only, according to diet composition (Á. Hernández unpubl. data). The following species were identified for the plant taxa shown at genus level: Populus spp.: P. nigra, P. × canadensis, occasionally P. tremula; Salix spp.: S. fragilis, S. atrocinerea, S. × secalliana; Rubus spp.: R. ulmifolius, R. caesius; Rosa spp.: R. canina; Malus spp.: M. domestica, M. sylvestris. Prunus spinosa includes $P$. insititia

for males, and from 3.05 to $4.41 \mathrm{~m}$, respectively, for females. In the case of juveniles, there was no significant combined effect of season and activity category on mean perch height $\left(F_{1,922}=2.09, P=0.15\right)$ and there were no seasonal differences when grouping activity categories together $\left(F_{1,922}=3.21, P=0.07 ; 3.34 \mathrm{~m}\right.$ in summer versus $3.85 \mathrm{~m}$ in autumn) (Fig. 4), but there were differences between activity categories if seasons are grouped together $\left(F_{1,922}=44.37, P<0.001 ; 2.79 \mathrm{~m}\right.$ when feeding versus $4.41 \mathrm{~m}$ when non-feeding). With regard to non-feeding male records, high values for the mean perch height of individuals singing in spring $(8.00$ $\pm 5.51 \mathrm{~m}$, range $=2-25 \mathrm{~m}, n=33)$ and summer $(6.52$ $\pm 3.34 \mathrm{~m}$, range $=2-14 \mathrm{~m}, n=23$ ) were found. 


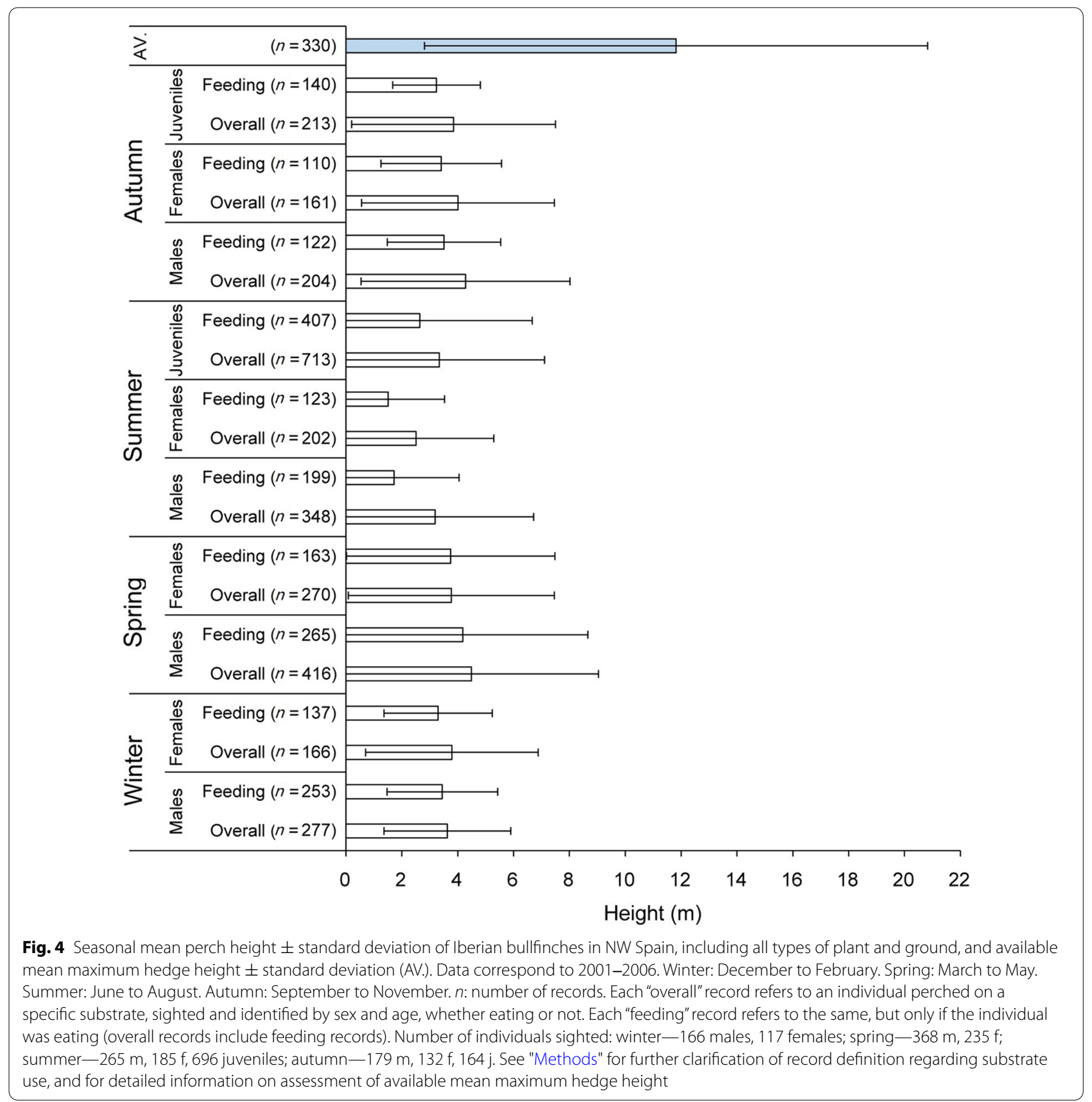

Mean perch heights occupied by bullfinches were clearly lower than the available mean maximum hedge height $(11.8 \mathrm{~m})$. This is confirmed statistically by comparing the latter with the highest values for overall (feeding plus non-feeding records) mean heights used by males, females and juveniles, i.e. males in spring ( 4.5 $\mathrm{m})$ and females and juveniles in autumn (4.0 and $3.8 \mathrm{~m}$, respectively) $\left(t_{744}=-14.43, t_{489}=-10.62, t_{541}=-\right.$ 12.27, respectively, $P<0.001$ in all three cases) (Fig. 4).

\section{Discussion}

\section{Main habitat components}

As expected, hedgerows were the key essential habitat component, as regards frequency of occurrence, for bullfinches throughout the year, that is, they consistently used the more prevalent structure of woody vegetation. Similarly, hedgerows were crucial as nest sites (Á. Hernández unpubl. data). This corroborates what is already known about how the species occupies 
heterogeneous semi-open landscapes with sufficient woody vegetation composed of large shrubs and trees all year round, mainly in western Europe including the Iberian Peninsula; and within these landscapes are the mosaics of mixed land use containing abundant hedgerows (Newton 1985; Cramp and Perrins 1994; Belamendia 2003, 2012; Clement 2010). In northern Spain, this type of farmland habitat is of great interest for the conservation of many bird species, including the bullfinch, in spring and winter (Tellería 1992; Tellería et al. 2008).

There were, however, significant changes in the composition of the bullfinch habitat during the year. It became more varied from winter, when other components except hedgerows were of little importance, to summer-autumn, when riverside woodland, irrigation ditches, dirt tracks bordered by shrubs and trees, and in particular poplar plantations, were more commonly used. Thus, in summer-autumn and spring, bullfinches preferred environments with more woody vegetation cover, including semi-open and closed-type hedgerows, in comparison with winter. In contrast to this, on a larger geographical scale, bullfinches appear to extend their habitat spectrum in winter, when they can be seen in very different landscapes besides woodland and farmland (e.g. cultivated areas, orchards, large gardens) both in Iberia and the rest of the western Palearctic, while maintaining their preference for more open landscapes during this time of the year (Greig-Smith and Wilson 1984; Woutersen and Platteeuw 1988; Cramp and Perrins 1994; Tellería et al. 1999; Marquiss 2007; Belamendia 2012). Passerine birds, including finches, are usually more demanding with regard to habitat during the breeding season than the rest of the year if they rely on suitable nest sites in woody vegetation (Alatalo 1981; Clement et al. 1993; Hernández 1994; Marone et al. 1997; MacLeod et al. 2004). Therefore, the influence of spatial scale in bullfinch habitat selection should be taken into consideration, as already indicated for birds in general (see review by Jones 2001).

Apparently, the seasonal variation in bullfinch habitat provided them with the necessary food, shade and shelter in summer and autumn. The effect of mowing and livestock grazing in the study area is noticeable from July, resulting in a marked decrease in herb seed availability, only found in a small number of unmown meadows and woody vegetation borders not adjacent to meadows (Á. Hernández pers. obs.). In line with this, the use of nesting zones with more trees and shade tended to increase as the breeding season progressed (Á. Hernández unpubl. data). Presumably, shelter was a much-needed requirement for fledglings and moulting individuals. Juveniles were the largest fraction of bullfinches observed during July-September, and from August it was generally more difficult to detect individuals in general, when they were less mobile, emitted fewer sounds and occupied apparently less accessible safer places, probably to favour survival during moult. Moulting bullfinches are observed mainly from August to October, and they prefer leafy humid sites (Newton 1966; Noval 1971; Â. Hernández unpubl. data). The selection of dense vegetation during the post-fledging period seems common in landbirds including forest songbirds, as well as the lack of coincidence, to a greater or lesser extent, between breeding and moulting habitats (Vitz and Rodewald 2011; Jenkins et al. 2017; Pyle et al. 2018). The higher occurrence of oak woodland edges and brushwood in the winter habitat is probably due to the relatively high supply of fleshy fruits in these plant formations, principally dried blackberries with available seeds, which are very appetizing for bullfinches in this season (Á. Hernández unpubl. data). In Scotland, in their search for available and proper food, bullfinches concentrate increasingly in heathlands during winter, where they feed on Common Heather (Calluna vulgaris) seeds through to February (Marquiss 2007). Food supply generally seems to have a great influence on avian habitat quality and its occupancy (Newton 1998; Dostine et al. 2001; Borras et al. 2010).

\section{Substrate selection}

Although bullfinches were mostly observed on shrubs/ trees throughout the year, there were significant seasonal changes in substrate use, ground and herbs being of considerable importance during spring-summer. Nevertheless, individuals sighted on the ground or herbs were usually very close $(<3 \mathrm{~m}$ distance) to the woody vegetation base, mainly hedgerows, occasionally moving 5-6 m at most into poplar plantations and meadows that had not been mowed or were invaded by shrubs (Á. Hernández pers. obs.). According to current information, that is, general considerations, the bullfinch does not usually show itself on the ground, and rarely more than 10 m from cover (Cramp and Perrins 1994; Marquiss 2007), which seems to vary monthly and between microhabitats. Also, throughout the year, over half of the records corresponded to feeding, reaching almost $90 \%$ in winter. This coincides with the length of time small birds spend foraging and feeding, which is typically longest in winter, when the days are shorter and colder, to maintain energy balance, even though activities associated with feeding may constitute almost $95 \%$ of the day for individuals involved in raising young (Goldstein 1988; Weathers and Sullivan 1993; Olsson et al. 2000).

Although individuals foraging did not necessarily feed on the plant they used as a perch, there was generally a close link between the most used/selected plant species and those most consumed in each season, mainly the buds and seeds of particular shrubs/trees/climbers 
and certain herb seeds, except for strongly selected large trees (poplars, willows) that probably provided above all shelter and higher substrates for singing and hunting insects and spiders (Á. Hernández pers. obs.). In the case of tree buds and tree seeds, there was a preference during specific periods for specific places in which the species involved were found, e.g. Fraxinus excelsior and Rubus brambles for seeds in winter, Prunus avium and P. spinosa for buds/flowers in spring, or Rubus brambles and Ligustrum vulgare for seeds in autumn (Á. Hernández pers. obs.). Bullfinches track their preferred fleshy fruit in autumn-winter in mountains in northwestern Iberia (Munilla and Guitián 2012), and can be considered fairly selective in their choice of food plants over the year (Cramp and Perrins 1994; Á. Hernández unpubl. data).

\section{Water bathing}

Bullfinches of different sexes and ages were seen bathing in all seasons except winter, mainly in the morning, taking turns and sometimes accompanied by other passerine species. In temperate latitudes, landbirds usually bathe throughout the year, in the morning and afternoon, more frequently in summer and on hot, sunny calm days, and less frequently in winter and on cold, cloudy/rainy, windy days (Slessers 1970; Stainton 1982). Although not verified, bullfinches probably bathed in winter in the study area, perhaps less assiduously and hidden on riverbanks as hardly any irrigation ditches contained water in this season. Most field trips were conducted in the morning all year round, which probably accounted for the low number of bath sightings in the afternoon. Turn-taking likely enabled individuals that were not bathing to keep guard. The main function of bathing is apparently feather maintenance, enhancing feather condition, flight performance and escape ability (Brilot et al. 2009; Brilot and Bateson 2012). Assemblages of several small bird species during bathing are relatively common (Cleary et al. 2016; Á. Hernández pers. obs.). Bullfinches bathe standing in shallow water, which is normal in many landbird species, and the different stages of behaviour observed coincide with those already described for this way of bathing by other authors (Slessers 1970; Verbeek 1991).

\section{Perch height}

Male bullfinches perched markedly higher than females, this difference being attributable mainly to non-feeding records, notably singing males in spring-summer. Several factors determine song perch height in passerine birds, including sound propagation and predator avoidance, and they generally choose higher perches for singing than other activities (Collins 1981; Greig-Smith 1983; Krams 2001; Blumenrath and Dabelsteen 2004). Although singing individuals seem to be at greater raptor predation risk than those not singing, and this risk grows with song perch height and exposure, it tends to be compensated for by improved vigilance and detection of potential predators, thus increasing the escape distance (Götmark and Post 1996; Krams 2001; Møller et al. 2006, 2008; Campos et al. 2009). Male bullfinches frequently sang from inside the upper part of shrubs and trees, in a relatively safer place (Á. Hernández pers. obs.). Also, males accompanied females during the breeding season, often at a greater height in a more exposed position and vigilant attitude, presumably partly associated with mate guarding, while the females carried out most of the tasks associated with the nest (Á. Hernández pers. obs.). Juveniles perched at a height not much lower than that of males. This is presumably attributable to the high percentages of records of dependent young accompanied by males during June-July, without females, which were probably attending new nests during those months (Á. Hernández pers. obs.).

Male bullfinches fed at greater heights than females in all seasons, possibly because of the subordinate status of the former, apparently assuming a greater role in vigilance (Á. Hernández unpubl. data). In passerine birds, socially dominant individuals usually select foraging sites to minimize predation risk, whereas subordinates forage in more predator risky places (Hogstad 2015 and references therein).

In general, bullfinches perched noticeably lower while feeding, except in spring when feeding height was considerable. In summer, they fed on lower perches than the rest of the year. Linked to this is the fact that buds/flowers of shrubs/trees, including tall cherry trees, were the main component in spring diet, herb seeds in summer diet, and the fleshy fruit of shrubs/climbers in autumnwinter diet (Á. Hernández unpubl. data). Mean heights occupied by bullfinches during the year did not reach half of the available mean maximum hedge height, that is, they concentrated their activity in the lower part of the available woody vegetation, and also on the ground and herbs during spring-summer. No quantitative analyses have been found in the literature on perch height selection by bullfinches, apart from vague descriptions such as their preference for staying in cover and feeding unobtrusively, for thick high shrubs, or for glades within tall trees (Cramp and Perrins 1994).

\section{Conclusions}

Bullfinches were mainly arboreal, but used ground and herb substrates during spring-summer, principally associated with food preferences and availability. They normally occupied the lowest strata of available woody vegetation, especially while foraging and above all females, although they used high perches in large trees 
to obtain some foods and, in the case of males, for singing. Linked to this, buds and flowers from shrubs and trees, including tall cherry trees, were the most common foods in spring, herb seeds in summer, and fleshy fruits from shrubs and climbers in autumn-winter. Hedgerow habitat seemed suitable for bullfinches in the study area, although the presence of different structural elements of vegetation, notably small poplar plantations, was important in order to meet particular ecological needs in certain seasons. All these various requirements should be taken into account in bullfinch conservation strategies.

\section{Acknowledgements}

I am grateful to two anonymous reviewers for their helpful suggestions. I wish to thank José Luis Robles and Pilar Zaldívar for reading the original manuscript and for their valuable comments. This paper is a research contribution of the Ecology and Conservation of Flora and Fauna Group at Valladolid University, Spain.

\section{Authors' contributions}

ÁH designed the study, carried out fieldwork, performed data analyses and wrote the manuscript. The author read and approved the final manuscript.

\section{Funding}

This research was not linked to specific funding. The author conducted the study as part of his work at the University of Valladolid, Spain, where he is associate professor of zoology.

\section{Availability of data and materials}

The main data of the study have been contained in the manuscript.

\section{Ethics approval and consent to participate}

All the fieldwork was performed using observational, non-invasive techniques which enabled sufficient data for the objectives of the study to be obtained without threatening the welfare of the birds, as they were not manipulated.

\section{Consent for publication}

Not applicable.

\section{Competing interests}

The author declares that he has no competing interests.

\section{Author details}

${ }^{1}$ Departamento de Ciencias Agroforestales, Área de Zoología, Universidad de Valladolid, Campus de Palencia, Palencia, España. ${ }^{2}$ Instituto Universitario de Investigación en Gestión Forestal Sostenible, Universidad de Valladolid, Campus de Palencia, Palencia, España.

Received: 7 June 2020 Accepted: 7 January 2021

Published online: 08 February 2021

\section{References}

Alatalo RV. Habitat selection of forest birds in the seasonal environment of Finland. Ann Zool Fenn. 1981;18:103-14.

Bas JM, Pons P, Gómez C. Daily activity of Sardinian Warbler Sylvia melanocephala in the breeding season. Ardeola. 2007;54:335-8.

Belamendia G. Camachuelo común, Pyrrhula pyrrhula. In: Martí R, del Moral $J C$, editors. Atlas de las aves reproductoras de España. Madrid: Dirección General de Conservación de la Naturaleza-Sociedad Española de Ornitologia; 2003. p. 592-3.

Belamendia G. Camachuelo común, Pyrrhula pyrrhula. In: del Moral JC, Molina B, Bermejo A, Palomino D, editors. Atlas de las aves en invierno en España 2007-2010. Madrid: Ministerio de Agricultura, Alimentación y Medio Ambiente-SEO/BirdLife; 2012. p. 534-5.
Blumenrath SH, Dabelsteen T. Degradation of great tit (Parus major) song before and after foliation: implications for vocal communication in a deciduous forest. Behaviour. 2004;141:935-58.

Borras A, Senar JC, Alba-Sánchez F, López-Sáez JA, Cabrera J, Colomé X, et al. Citril finches during the winter: patterns of distribution, the role of pines and implications for the conservation of the species. Anim Biodivers Conserv. 2010;33:89-115.

Brilot BO, Bateson M. Water bathing alters threat perception in starlings. Biol Lett. 2012;8:379-81.

Brilot BO, Asher L, Bateson M. Water bathing alters the speed-accuracy tradeoff of scape flights in European starlings. Anim Behav. 2009;78:801-7.

Campos DP, Bander LA, Raksi A, Blumstein DT. Perch exposure and predation risk: a comparative study in passerines. Acta Ethol. 2009;12:93-8.

Cleary GP, Parsons H, Davis A, Coleman BR, Jones DN, Miller KK, et al. Avian assemblages at bird baths: a comparison of urban and rural bird baths in Australia. PLoS ONE. 2016;11(3):e0150899.

Clement P. Eurasian Bullfinch Pyrrhula pyrrhula. In: Del Hoyo J, Elliott A, Christie DA, editors. Handbook of the birds of the world, vol 15: weavers to New World warblers. Barcelona: Lynx Edicions; 2010. p. 609-10.

Clement P, Harris A, Davis J. Finches and sparrows. London: Helm; 1993.

Cody ML. An introduction to habitat selection in birds. In: Cody ML, editor. Habitat selection in birds. Orlando: Academic Press; 1985. p. 3-56.

Collins SL. A comparison of nest-site and perch-site vegetation structure for seven species of warblers. Wilson Bull. 1981:93:542-7.

Cornulier T, Robinson RA, Elston D, Lambin X, Sutherland WJ, Benton TG. Bayesian reconstitution of environmental change from disparate historical records: hedgerow loss and farmland bird declines. Methods Ecol Evol. 2011;2:86-94.

Cramp S, Perrins CM. The birds of the western Palearctic, vol 8: crows to finches. Oxford: Oxford University Press; 1994.

De Groot M, Kmecl P, Figelj A, Figelj J, Mihelič T, Rubinić B. Multi-scale habitat association of the ortolan bunting Emberiza hortulana in a sub-Mediterranean area in Slovenia. Ardeola. 2010;57:55-68.

Díaz L. Camachuelo común Pyrrhula pyrrhula. In: Salvador A, Morales MB, editors. Enciclopedia virtual de los vertebrados españoles. Madrid: Museo Nacional de Ciencias Naturales. 2016. http://www.vertebradosibericos. org/aves/pyrpyr.html. Accessed 07 May 2020.

Dostine PL, Johnson GC, Franklin DC, Zhang Y, Hempel C. Seasonal use of savanna landscapes by the Gouldian finch, Erythrura gouldiae, in the Yinberrie Hills area, Northern Territory. Wildl Res. 2001;28:445-58.

Farina A. Landscape structure and breeding bird distribution in a sub-Mediterranean agro-ecosystem. Landscape Ecol. 1997;12:365-78.

Fourcade Y, Besnard AG, Beslot E, Hennique S, Mourgaud G, Berdin G, et al. Habitat selection in a dynamic seasonal environment: vegetation composition drives the choice of the breeding habitat for the community of passerines in floodplain grasslands. Biol Conserv. 2018;228:301-9.

Fowler J, Cohen L, Jarvis P. Practical statistics for field biology. 2nd ed. Chichester: Wiley; 1998.

García-del-Rey E, Cresswell W. Density estimates, microhabitat selection and foraging behaviour of the endemic Blue Chaffinch Fringilla teydea teydea on Tenerife (Canary Islands). Ardeola. 2005;52:305-17.

Ghasemi A, Zahediasl S. Normality tests for statistical analysis: a guide for nonstatisticians. Int J Endocrinol Metab. 2012;10:486-9.

Glutz von Blotzheim UN, Bauer KM. Handbuch der Vögel Mitteleuropas. Band 14. Passeriformes (5. Teil). II: Fringillidae. Wiesbaden: Aula-Verlag; 1997.

Goldstein DL. Estimates of daily energy expenditure in birds: the timeenergy budget as an integrator of laboratory and field studies. Am Zool. 1988;28:829-44.

Götmark F, Post P. Prey selection by sparrowhawks, Accipiter nisus: relative predation risk for breeding passerine birds in relation to their size, ecology and behaviour. Phil Trans R Soc Lond B. 1996;351:1559-77.

Gregory RD, Baillie SR. Large-scale habitat use of some declining British birds. J Appl Ecol. 1998;35:785-99.

Gregory RD, Noble DG, Custance J. The state of play of farmland birds: population trends and conservation status of lowland farmland birds in the United Kingdom. Ibis. 2004;146(Suppl 2):1-13.

Greig-Smith PW. Use of perches as vantage points during foraging by male and female stonechats Saxicola torquata. Behaviour. 1983;86:215-36.

Greig-Smith PW, Wilson GM. Patterns of activity and habitat use by a population of bullfinches (Pyrrhula pyrrhula) in relation to bud-feeding in orchards. J Appl Ecol. 1984;21:401-22. 
Guitián J, Munilla I. Resource tracking by avian frugivores in mountain habitats of northern Spain. Oikos. 2008;117:265-72.

Hancock MH, Wilson JD. Winter habitat associations of seed-eating passerines on Scottish farmland. Bird Study. 2003;50:116-30.

Hernández Á. Selección de hábitat en tres especies simpátricas de alcaudones Lanius spp.: segregación interespecífica. Ecología. 1994;8:395-413.

Hernández Á. Summer-autumn feeding ecology of Pied Flycatchers Ficedula hypoleuca and Spotted Flycatchers Muscicapa striata: the importance of frugivory in a stopover area in north-west Iberia. Bird Conserv Int. 2009;19:224-38

Hernández Á. Seasonal habitat use in Eurasian red squirrels residing in Iberian hedgerows. Hystrix. 2014;25:95-100.

Hernández Á. Diet of Eurasian Sparrowhawks in a Northwest Iberian hedgerow habitat throughout the year. Ornithol Sci. 2018;17:95-101.

Hernández Á. Breeding ecology of Eurasian bullfinches Pyrrhula pyrrhula in an Iberian hedgerow habitat. J Nat Hist. 2021. https://doi. org/10.1080/00222933.2020.1860263.

Hernández Á, Alegre J. Estructura de la comunidad de Passeriformes en setos de la provincia de León (noroeste de España). Doñana Acta Vertebr. 1991;18:237-50.

Hernández Á, Zaldívar P. Epizoochory in a hedgerow habitat: seasonal variation and selective diaspore adhesion. Ecol Res. 2013;28:283-95.

Hernández Á, Zaldívar P. Ecology of stoats Mustela erminea in a valley of the Cantabrian Mountains, northwestern Spain. Vertebr Zool. 2016;66:225-38.

Herrera CM. Habitat-consumer interactions in frugivorous birds. In: Cody ML, editor. Habitat selection in birds. Orlando: Academic Press; 1985. p. 341-65.

Hinsley SA, Bellamy PE. The influence of hedge structure, management and landscape context on the value of hedgerows to birds: a review. J Environ Manage. 2000;60:33-49.

Hogstad O. Rank-related response in foraging site selection and vigilance behaviour of a small passerine to different winter weather conditions. Ornis Fenn. 2015;92:53-62.

Huang Q, Swatantran A, Dubayah R, Goetz SJ. The influence of vegetation height heterogeneity on forest and woodland bird species richness across the United States. PLOS ONE. 2014;9(8):e103236.

Jacobs J. Quantitative measurement of food selection. A modification of forage ratio and Ivlev's electivity index. Oecologia. 1974;14:413-7.

Jenkins JMA, Thompson FR III, Faaborg J. Species-specific variation in nesting and postfledging resource selection for two forest breeding migrant songbirds. PLoS ONE. 2017;12(6):e0179524.

Jones J. Habitat selection studies in avian ecology: a critical review. Auk. 2001;118:557-62.

Krams I. Perch selection by singing chaffinches: a better view of surroundings and the risk of predation. Behav Ecol. 2001;12:295-300.

Lowry R. VassarStats: website for statistical computation. 1998-2020. http:// vassarstats.net. Accessed 12 September 2020.

MacLeod CJ, Parish DMB, Hubbard SF. Habitat associations and breeding success of the Chaffinch Fringilla coelebs. Bird Study. 2004:51:239-47.

Marone L, López de Casenave J, Cueto VR. Patterns of habitat selection by wintering and breeding granivorous birds in the central Monte desert, Argentina. Rev Chil Hist Nat. 1997;70:73-81.

Marquiss M. Seasonal pattern in hawk predation on common bullfinches Pyrrhula pyrrhula: evidence of an interaction with habitat affecting food availability. Bird Study. 2007:54:1-11.

Marra PP, Cohen EB, Loss SR, Rutter JE, Tonra CM. A call for full annual cycle research in animal ecology. Biol Lett. 2015;11:20150552.

Martínez D, García D. Disentangling habitat use by frugivorous birds: constant interactive effects of forest cover and fruit availability. Basic Appl Ecol. 2015:16:460-8.

Møller AP, Nielsen JT, Garamszegi LZ. Song post exposure, song features, and predation risk. Behav Ecol. 2006;17:155-63.

Møller AP, Nielsen JT, Garamszegi LZ. Risk taking by singing males. Behav Ecol. 2008:19:41-53.

Munilla I, Guitián J. Numerical response of Bullfinches Pyrrhula pyrrhula to winter seed abundance. Ornis Fenn. 2012;89:197-205.

Newton I. The moult of the Bullfinch Pyrrhula pyrrhula. Ibis. 1966;108:41-87.

Newton I. Finches. Limpback ed. London: Collins; 1985.

Newton I. Population limitation in birds. San Diego: Academic Press; 1998.
Newton I. The recent declines of farmland bird populations in Britain: an appraisal of causal factors and conservation actions. Ibis. 2004:146:579-600.

Noval A. Movimientos estacionales y distribución del camachuelo común, Pyrrhula pyrrhula iberiae, en el norte de España. Ardeola. 1971;special issue:491-507.

Olsson O, Wiktander U, Nilsson SG. Daily foraging routines and feeding effort of a small bird feeding on a predictable resource. Proc $\mathrm{R}$ Soc Lond B. 2000;267:1457-61.

Phillimore AB, Owens IPF. Are subspecies useful in evolutionary and conservation biology? Proc R Soc B. 2006;273:1049-53.

Pyle P, Saracco JF, DeSante DF. Evidence of widespread movements from breeding to molting grounds by North American landbirds. Auk. 2018:135:506-20.

Rechetelo J, Grice A, Reside AE, Hardesty BD, Moloney J. Movement patterns, home range size and habitat selection of an endangered resource tracking species, the black-throated finch (Poephila cincta cincta). PLOS ONE. 2016;11:e0167254.

Rice J, Anderson BW, Ohmart RD. Seasonal habitat selection by birds in the lower Colorado River Valley. Ecology. 1980;61:1402-11.

Ríos-Saldaña CA, Delibes-Mateos M, Ferreira CC. Are fieldwork studies being relegated to second place in conservation science? Glob Ecol Conserv. 2018;14:e00389.

Rivas-Martínez S. Mapa de series, geoseries y geopermaseries de vegetación de España. Itinera Geobot. 2007;17:1-436.

Robinson RA, Sutherland WJ. The winter distribution of seed-eating birds: habitat structure, seed density and seasonal depletion. Ecography. 1999;22:447-54.

Siriwardena GM, Crick HQP, Baillie SR, Wilson JD. Agricultural habitat-type and the breeding performance of granivorous farmland birds in Britain. Bird Study. 2000;47:66-81.

Siriwardena GM, Crick HQP, Baillie SR, Wilson JD. Agricultural land-use and the spatial distribution of granivorous lowland farmland birds. Ecography. 2000:23:702-19.

Slessers M. Bathing behavior of land birds. Auk. 1970;87:91-9.

Stainton JM. Timing of bathing, dusting and sunning. Br Birds. 1982;75:65-86.

Stoate C, Szczur J, Aebischer NJ. Winter use of wild bird cover crops by passerines on farmland in northeast England. Bird Study. 2003;50:15-21.

Streby HM, Refsnider JM, Peterson SM, Andersen DE. Retirement investment theory explains patterns in songbird nest-site choice. Proc R Soc B. 2014;281:20131834

Sutherland WJ. Diet and foraging behavior. In: Sutherland WJ, Newton I, Green $\mathrm{R}$, editors. Bird ecology and conservation. A handbook of techniques. Oxford: Oxford University Press; 2004. p. 233-50.

Tellería JL. Gestión forestal y conservación de las aves en España peninsular. Ardeola. 1992;39:99-114.

Tellería JL, Pérez-Tris J. Habitat effects on resource tracking ability: do wintering Blackcaps Sylvia atricapilla track fruit availability? Ibis. 2007;149:18-25.

Tellería JL, Asensio B, Díaz M. Aves ibéricas. II. Passeriformes. Madrid: JM Reyero Ediciones; 1999

Tellería JL, Ramírez A, Galarza A, Carbonell R, Pérez-Tris J, Santos T. Geographical, landscape and habitat effects on birds in northern Spanish farmlands: implications for conservation. Ardeola. 2008;55:203-19.

Temple SA. Individuals, populations, and communities: the ecology of birds. In: Podulka S, Rohrbaugh Jr. RW, Bonney R, editors. Handbook of bird biology. Ithaca: Cornell Lab of Ornithology-Princeton University Press; 2004. p. 9.1-9.134.

Verbeek NAM. Comparative bathing behavior in some Australian birds. J Field Ornithol. 1991;62:386-9.

Vitz AC, Rodewald AD. Influence of condition and habitat use on survival of post-fledging songbirds. Condor. 2011;113:400-11.

Weathers WW, Sullivan KA. Seasonal patterns of time and energy allocation by birds. Physiol Zool. 1993;66:511-36.

Wiens JA. The ecology of bird communities, vol. 1. Foundations and patterns Cambridge: Cambridge University Press; 1989.

Wilkinson R. Vocal behaviour and call development in the bullfinch (Pyrrhula pyrrhula). Bioacoustics. 1990;2:179-97.

Wilson JD, Evans AD, Grice PV. Bird conservation and agriculture. Cambridge: Cambridge University Press; 2009.

Woutersen K, Platteeuw M. Atlas de las aves de Huesca: observaciones de aves en el Alto Aragón. Huesca: Kees Woutersen Publicaciones; 1988. 